Luque-Fernández, C.R., Caballero, K., Pauca, G.A., Villegas, L., Alcelay, I., \& Machaca, J. (2021). Unmanned aerial vehicle, and GIS tools, to monitor the reproduction of the flamingo Phoenicopterus chilensis (Aves: Phoenicopteridae). Revista de Biología Tropical, 69(2), 000-000. https://doi.org/

\title{
Unmanned aerial vehicle, and GIS tools, to monitor the reproduction of the flamingo Phoenicopterus chilensis (Aves: Phoenicopteridae)
}

\author{
César R. Luque-Fernández ${ }^{1 *}$; (D) https://orcid.org/0000-0001-8050-461X \\ Kenny Caballero2; (D) https://orcid.org/0000-0003-4487-3068 \\ Gregory Anthony Pauca ${ }^{1}$; (D) https://orcid.org/0000-0001-6367-5345 \\ Luis Villegas 3 ; (D) https://orcid.org/0000-0002-7605-4326 \\ Ibai Alcelay1; (D https://orcid.org/0000-0002-5512-5025 \\ John Machaca ${ }^{4}$; (D) https://orcid.org/0000-0003-4901-7738
}

1. Universidad Nacional de San Agustín de Arequipa, Arequipa, Perú; cluquef@unsa.edu.pe (*Correspondence), gpaucat@unsa.edu.pe, alcelaybai@gmail.com

2. Centro de Estudios y Promoción del Desarrollo del Sur (DESCOSUR), Arequipa, Perú; kenny@descosur.org.pe

3. Escuela de Posgrado, Universidad Católica de Santa María, Arequipa, Perú; lvillegasp@unsa.edu.pe

4. Reserva Nacional Salinas y Aguada Blanca (RNSyAB), Servicio Nacional de Áreas Naturales Protegidas por el Estado (SERNANP), Arequipa, Perú; jmachaca@sernanp.gob.pe

$$
\text { Received 11-II-2021. Corrected 11-V-2021. Accepted 10-VI-2021. }
$$

\begin{abstract}
Introduction: High Andean flamingos also known as parihuanas, are species of recurrent presence in the high Andean areas which find this area as an important resting, feeding and in some cases breeding area The species recorded here correspond to Phoenicoparrus jamesi, Phoenicoparrus andinus and Phoenicopterus chilensis, the latter being the most abundant and common. During the censuses performed during 2018 and 2019, in the high Andean lake of Salinas, Ramsar site, located within the Reserva Nacional Salinas y Aguada Blanca in Southern Peru, atypical behaviors of these birds were recorded in a sector of the lake, observing reproductive courtship and the settlement of colonies of P. chilensis. Objective: The study aimed to confirm and evaluate reproductive events of $P$. chilenesis (Chilean flamingo) through the use of an unmanned aerial vehicle (UAV) and image processing tools using geographic information systems. Methodology: Monitoring was conducted during 2018 and 2019 to breeding colonies of P. chilensis, we used a UAV Phantom 4 testing different flight altitudes to avoid disturbing the birds and performed records of aerial photographs and GIS post-processing with the creation of panchromatic images for the identification and counting of individuals and eggs automated, and manual verification. Results: During 2018 were identified nests and presence of six eggs, this occurred between March and June where the event was interrupted not observing chicks or juveniles during this period, for 2019 the breeding was more successful, where a higher number of eggs were counted (40-66) and with the formation of three reproductive colonies with 4185 adult individuals, also verified the presence of chicks and juveniles that reached a maximum of 1491 individuals. Conclusions: We confirmed two continuous reproductive events of $P$. chilensis in the Salinas lake, where during 2019 was the most successful incorporating several new individuals to the initial population, likewise the methodology applied in the image processing allowed differentiating between adult individuals and eggs but did not allow differentiating juveniles, however, the images directly acquired by the UAV allow distinguishing the types of individuals to perform a manual count.
\end{abstract}

Key words: parihuana; nesting; breeding; remote sensing; drone. 
High Andean flamingos, parinas or parihuanas (Phoenicopteridae), are birds with a distinctive plumage color, ranging from shades of pink and purple to salmon, currently there are six species distributed in America, Africa and Eurasia (Mendoza et al., 2013). Flamingos are gregarious and long-lived birds that inhabit mostly hypersaline, salty and shallow aquatic environments, and can be found from sea level to above 5000 m.a.s.l. They are birds highly specialized in plankton feeding, usually prefer lakes or lagoons with a high concentration of salts and food, in which they often use also for breeding (Hurlbert \& Keith, 1979; Martínez \& González, 2017; Winkler et al., 2020). Three species are currently reported in Peru and are typical of the Andean Altiplano of South America: Jame's Flamingo or puna parihuana (Phoenicoparrus jamesi), Andean Flamingo or Andean parihuana (Phoenicoparrus andinus) and Chilean Flamingo or common parihuana (Phoenicopterus chilensis); being P. chilensis the most widespread, distributing from North to South of Peru and classified as a common and resident species (Hurlbert \& Keith, 1979; Schulenberg et al., 2010). Flamingo populations are vulnerable due to the fragility of the habitats they reside in, in addition to other threats such as predation risk and anthropogenic disturbances, which also condition their abundance and distribution (Barisón et al., 2014). The current conservation status of the Chilean flamingo is "Near Threatened" by the IUCN (BirdLife International, 2018), also included in CITES Appendix II, and by national categorization as by the Peruvian State as "Near Threatened" (Supreme Decree N-004-2014-MINAGRI).

The largest populations of Chilean flamingo are found in Argentina, Bolivia and Chile, especially in the reproductive season (Caziani et al., 2007), however in Peru there are few reports about these events or nidification sites (Ugarte-Núñez \& Mosaurieta-Echegaray, 2000; Rodríguez, 2005) and have been little studied and monitored. With the development of new technologies and their low costs, a change in research methodologies is occurring
(Grémillet et al., 2012). For example, the case of unmanned aerial vehicles (UAV) are becoming more and more common (Borrelle \& Fletcher, 2017), especially in ornithological studies (Chabot et al., 2015; Dulava et al., 2015; McClelland et al., 2016) and specifically in the case of flamingos (Vas et al., 2015), it has been concluded that they do not produce significant disturbances in their populations, offering greater efficiency in the observation of individuals in incubation and juveniles, accounting in general terms a greater number of individuals compared to observations made from land (Sabella et al., 2017; Vas et al., 2015).

This research aims to evaluate the unusual reproductive events recorded in the population of the $P$. chilensis in the high Andean lake of Salinas, in a protected natural area in Southern Peru, which had not been previously reported as an active breeding site of this species for more than 20 years. Additionally, we incorporated the monitoring of these events with the use of an unmanned vehicle (UAV) and developed a methodology for the processing and quantification of individuals and the detection of eggs through the implementation of GIS tools.

\section{MATERIALS AND METHODS}

Study site: The study area corresponds to Salinas lake, a high Andean Salt Lake, which has been recognized as a Ramsar site since 2003. Politically it is located between Arequipa and Moquegua regions, in Southern Peru, that adjacent to three peasant communities (Salinas Huito, Salinas Moche and Santa Lucia de Salinas); within the Reserva Nacional de Salinas y Aguada Blanca (RNSyAB), which is under the management of the Servicio Nacional de Áreas Naturales Protegidas por el Estado (SERNANP). This wetland is located in an endorheic basin, supplied mainly by rainwater, at an altitude of 4300 m.a.s.l., it covers an area of 6182 ha and it is surrounded by a large area of hydrophytic vegetation (bofedales). In addition, the lake is the site of economic activities such as boron salt extraction by the INKABOR 
mining company, salt extraction, and grazing of domestic South American camelids (alpacas and llamas) by residents of rural communities.

Monitoring colonies of Chilean flamingos: As a background to this research, since 2012, joint monitoring has been carried out in the Salinas lake by the participating entities (SERNANP, DESCO and the INKABOR Company), to know the population dynamics of the water birds in this lake. But, during the monitoring surveys conducted in 2018 and 2019, unusual behaviors were recorded in the Chilean Flamingo population, where reproductive rituals were exhibited by a large group of these animals (in both years starting in February), resulted in the establishment of three closely spaced colonies in the Northeastern sector of the lake $\left(16^{\circ} 22^{\prime} 7.30^{\prime \prime} \mathrm{S} \& 71^{\circ} 8^{\prime} 32.98^{\prime \prime} \mathrm{W}\right)$, which were evaluated for this research (Fig. 1). In addition, although two other species of flamingos (Phoenicoparrus jamesi, Phoenicoparrus andinus) also occur in the study area, they were not present in the breeding colonies evaluated in any years.

Instruments and evaluation parameters: The observation and monitoring of the reproductive colonies of the Chilean flamingo were performed with aerial shots from an unmanned aerial vehicle (UAV), Phamton 4 Advance, white color, with an integrated 20-megapixel camera.

To establish the UAV flight parameters, the methodology used by Vas et al. (2015) was used as a reference, to avoid or reduce possible disturbances caused by the UAV during the flight. Overflights of $30 \mathrm{~min}$ were made in the direction of the identified colonies, being the height of the initial flight $100 \mathrm{~m}$ with a displacement of $6 \mathrm{~m} / \mathrm{s}$. Once the location of the flamingo's colony was located, a slow descent was made over the colony with pauses every $10 \mathrm{~m}$, to verify any disturbance was caused in the overflown colonies; the approach limit was never less than $30 \mathrm{~m}$ in height, at this height the

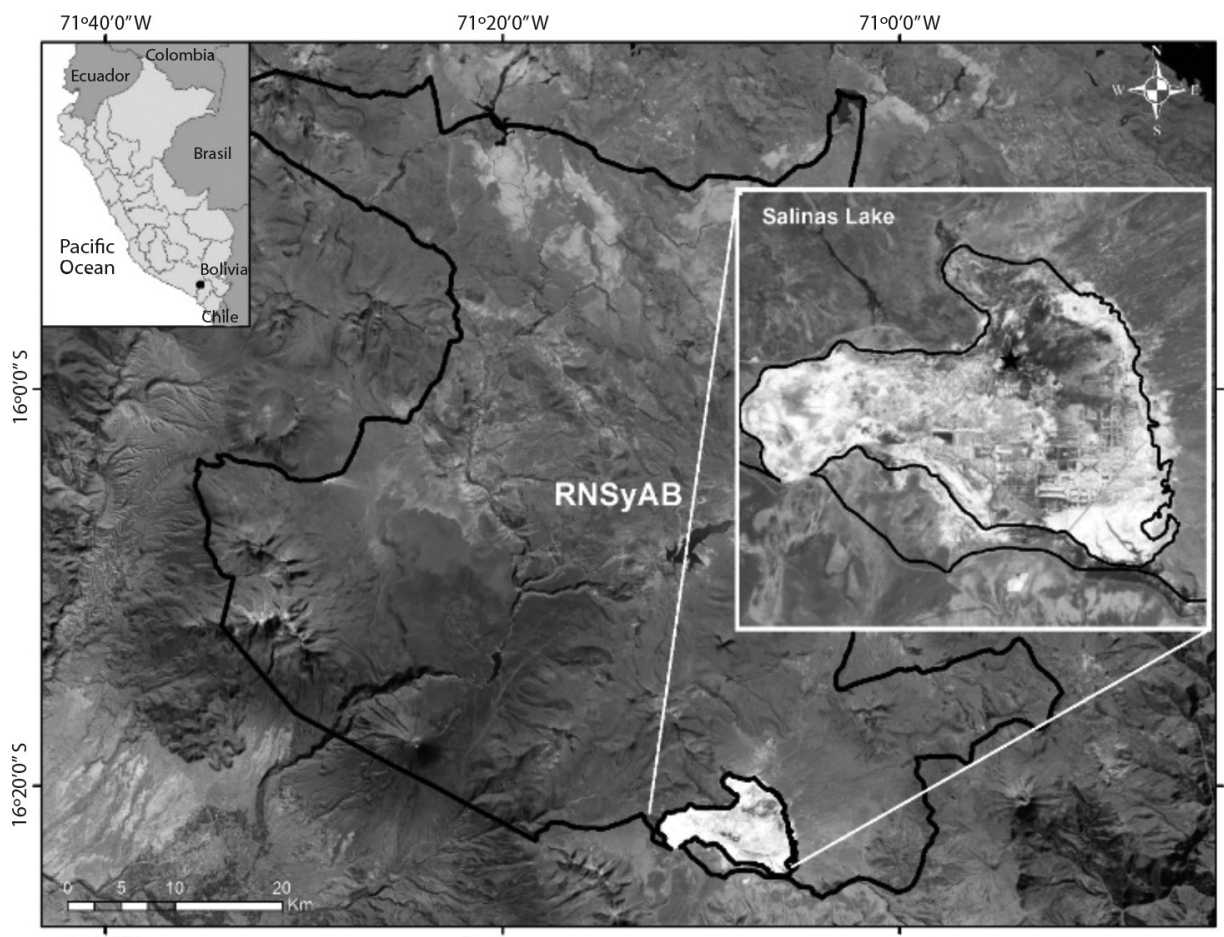

Fig. 1. Location of the evaluation sector of the Chilean Flamingo colonies (black star) in Salinas Lake, Arequipa, Peru. 
birds showed stress behaviors. Once the proper height of the UAV was established, we proceeded to take the photo sequences (JPEG and RAW), as well as short videos for subsequent analysis. The UAV flights were made between 09:00 and 12:00 h., to avoid or reduce shadows in the photographs and reduce bias when analyzing the images. Moreover, later at this time, the wind speed increases in the study area, putting at risk the flight of the UAV.

Image processing: The UAV photographs were processed and analyzed with ArcGis 10.3 software. Initially, the images were georeferenced and sorted to obtain an RGB orthophoto of each colony. Subsequently, each orthophoto was analyzed for principal components to obtain a panchromatic image, which using a pixel value analysis, the range of values covering flamingos and eggs was selected. Once the "pixel values" were identified, the program was instructed to classify the panchromatic image based on the values obtained, using the reclassification tool.

The result was then converted into a shapefile (*.shp), and the table of attributes was exported to an Excel sheet to make the respective postings. Once the images and final values were obtained, Chilean flamingo individuals and eggs were quantified. In addition, verification was performed by manual count on the photographs, to establish the number of individuals and the presence of observable nests and eggs.

\section{RESULTS}

Reproductive events of Chilean flamingo: In 2018, the reproductive event of $P$. chilensis was confirmed between March and June (transitional season between wet and dry seasons), observing a single nesting colony $\left(16^{\circ} 21^{\prime} 26.47^{\prime \prime} \mathrm{S} \& 71^{\circ} 7^{\prime} 46.62^{\prime \prime} \mathrm{W}\right)$, with an extension of $689 \mathrm{~m}^{2}$. In the evaluation by the end of March with the UAV images, 06 nests with eggs and 462 adult individuals in incubation positions could be differentiated (Fig. 2). The ideal altitude of approximation without disturbing the flamingo colony was $30 \mathrm{~m}$. By April and early June, according to observations at the site, the individuals of the colony were dispersing throughout the lake, apparently, the

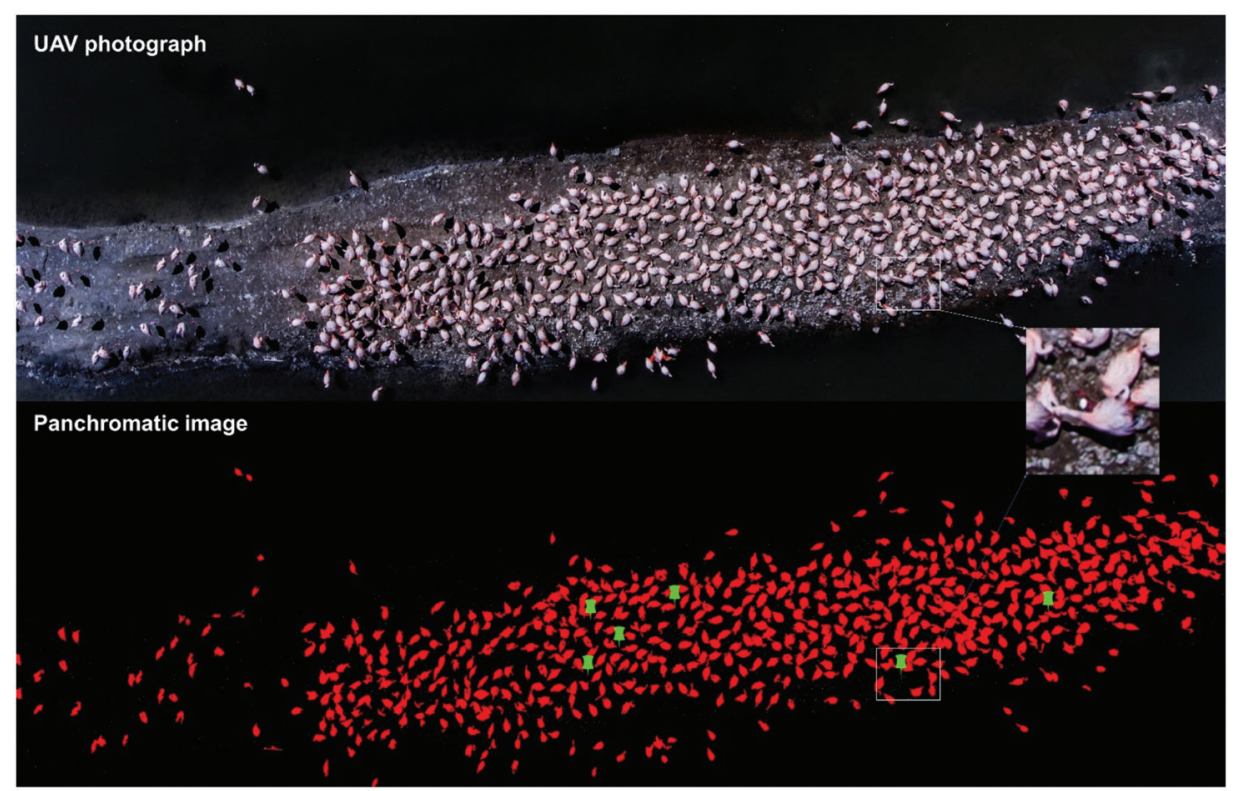

Fig. 2. Evaluation image of 2018 for Chilean flamingo nesting event in Laguna de Salinas, showing original photo and RGB image processing acquired with UAV (Phamton 4), where: red polygons - adult individuals; green dots - nest with egg. 
nesting attempt was unsatisfactory, since no flamingo chicks were observed at the end of this evaluation.

In 2019, the first evaluation with the UAV was carried out in July, where three active nesting colonies were observed (Colony 1: $250 \mathrm{~m}^{2}$, Colony 2: $843 \mathrm{~m}^{2}$ and Colony 3: 530 $\mathrm{m}^{2}$ ), observing a total of 4185 adult individuals in the three colonies, where around $40 \%$ were incubating (Fig. 3A); it was also possible to identify 40 eggs in the three colonies, which were correctly determined by both the remote sensing method and the visual verification method. Also, 973 juvenile individuals of Chilean flamingo were counted (juveniles and chicks were considered), this was done only manually, being the best method for quantifying these individuals because the image classification showed a high error rate. The ideal altitude of approximation without causing disturbance to the flamingo colony was $40 \mathrm{~m}$ above them. At the beginning of August
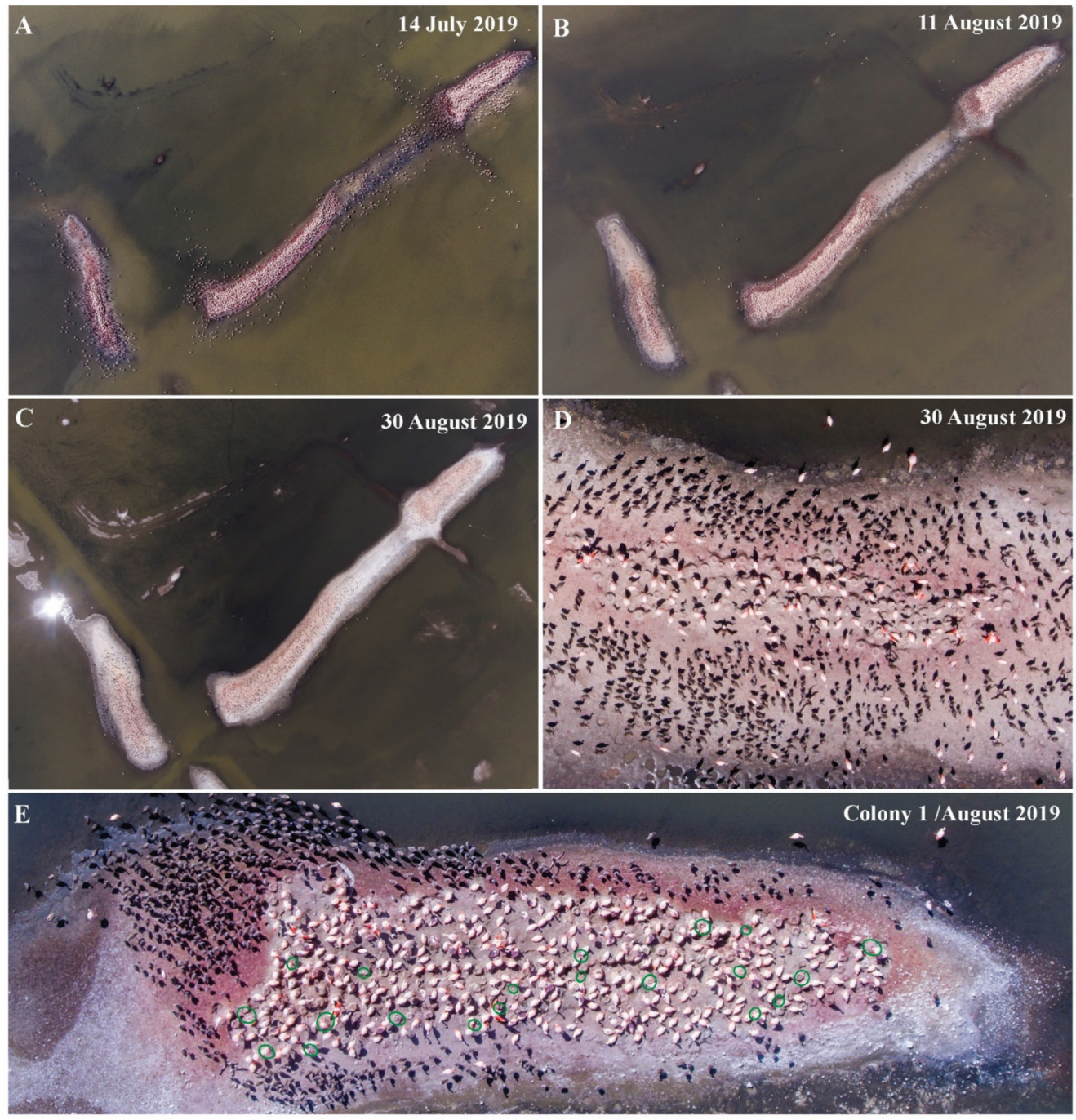

Fig. 3. Panoramic photos of the nesting event during 2019 from UAV. A. Nesting colonies in July; B. Nesting colonies at the beginning of August; C. Final assessment of late August; D. Detail of nests and adult individuals in the central part, juveniles (gray) around the colony; E. Colony 1 during August 2019 showing the location of identified eggs (green rings). 
(Fig. 3B), 1094 adults were counted in the nesting colonies, where $80 \%$ were incubating; a notable increase was observed in the number of juveniles, 1425 individuals, almost double the number reported in July; and 66 eggs were also identified (Fig. 3E), confirming the continuity of the reproductive event.

Due to the presence of juveniles with different plumage and sizes, for this evaluation, the flight parameter with the UAV was modified, establishing a height of $50 \mathrm{~m}$ above the ground, since, at a lower height, juvenile and adult individuals began showing signs of stress, which did not occur in the previous evaluation in July. The behavior observed was that juveniles began to aggregate and move between the colonies, and some adults ("bird-sitter") began flapping continuously and trying to guide the juveniles (Luque-Fernández, 2021; https:// www.youtube.com/watch? $v=152 \mathrm{Pmp} 9 \mathrm{PxFc}$ ).

By the end of August, a decrease in the number of adult individuals was observed in the nesting colonies (488 individuals) compared to the previous months; the number of juveniles increased slightly over the previous evaluation (Fig. 3C). Eggs could not be observed or identified in this evaluation, although some adult individuals continued in the incubation position, which could be confirmed by the photos and videos recorded. Likewise, it was possible to observe in more detail the nests used by the
Chilean flamingos (Fig. 3D). In this evaluation, several individuals (juveniles) were sighted in different locations of Salinas lake and bofedales. The flight parameter for this evaluation was a $60 \mathrm{~m}$ height above the colonies.

A consistent fluctuation was observed between the values of adult and juvenile individuals over time, as the number of adult individuals incubating decreased, with an inverse relationship to the number of juveniles that appeared (Table 1), where could be estimated an increase of more than 1500 new individuals to the population of Chilean flamingo to Salinas lake and its general population, which added to ongoing evaluations show the site as ideal for successful reproductive events as reported.

\section{DISCUSSION}

About nesting event of Chilean flamingo population, results confirm satisfactory reproductive events of the Chilean flamingo in a Salinas lake sector, during 2018 and 2019. These would be the first documented records of this species reproduction in this high Andean wetland, after almost 20 years, despite that reported the existence of nesting areas (UgarteNúñez \& Mosaurieta-Echegaray, 2000), but without mentioning that they were active.

Until 2005, for the entire distribution range of the $P$. chilensis, a total of 17 reproduction

TABLE 1. Number of individuals (adults and juveniles) and eggs for each evaluation during 2019 in Salinas Lake, Arequipa, Peru

\begin{tabular}{|c|c|c|c|c|c|}
\hline \multirow{2}{*}{ Date } & \multirow{2}{*}{ Colony } & \multicolumn{2}{|c|}{ Adults } & \multirow{2}{*}{ Juvenile } & \multirow{2}{*}{ Eggs } \\
\hline & & Standing & Sitting & & \\
\hline \multirow[t]{3}{*}{$14 / 07 / 2019$} & 1 & 386 & 153 & 340 & 15 \\
\hline & 2 & 1181 & 918 & 117 & 13 \\
\hline & 3 & 992 & 555 & 516 & 12 \\
\hline Total & & 2559 & 1626 & 973 & 40 \\
\hline \multirow[t]{3}{*}{$11 / 08 / 2019$} & 1 & 22 & 11 & 404 & 20 \\
\hline & 2 & 130 & 561 & 570 & 40 \\
\hline & 3 & 44 & 326 & 451 & 6 \\
\hline Total & & 196 & 898 & 1425 & 66 \\
\hline \multirow[t]{3}{*}{$30 / 08 / 2019$} & 1 & 72 & 17 & 655 & 0 \\
\hline & 2 & 198 & 61 & 490 & 0 \\
\hline & 3 & 112 & 28 & 346 & 0 \\
\hline Total & & 382 & 106 & 1491 & 0 \\
\hline
\end{tabular}


sites had been identified in Puna areas (Rodríguez, 2005), reporting a single site for Peru in Junín Lake (Junín), during the 70 s and 80 s. Later, for this area, reproduction reports were also made between 2003 and 2008 (Asociación Ecosistemas Andinos, 2010) and more recently there have been events recorded in the Ite wetland (Tacna) on the South coast (Vizcarra, 2014). These reports, in addition to this study, could change the classification of the Chilean flamingo, as a reproductive visitor in Peru (Schulenberg et al., 2010).

Regarding the number of new individuals of Chilean flamingo added to the population, this event would represent the largest record reported for Peru (Asociación Ecosistemas Andinos, 2010), where it is estimated that in 2019 around 1500 individuals were born. These values are higher than those recorded for Chile, which has eight nesting sites out of the 17 reported (Rodríguez, 2005), where no more than 1250 individuals had been registered in each one during a single reproduction event, except for Surire Salar locality where 7500 individuals were recorded.

The chronology of the reproductive event observed in Salinas lake, agrees with the literature (Rodríguez, 2005), where copulation usually occurs during May, and a large amount of egg is laid during June and July, and dispersion of the new individuals occurs at the end of August. In addition to this, it has not been ruled the possibility of consecutive egg-laying events having a place, which would respond to the good site conditions (Henriksen et al., 2015; Krienitz et al., 2016; Martínez \& González, 2017; Polla et al., 2018).

The analysis of the images obtained through the UAV allowed to identify correctly and estimate the number of individuals and eggs, the methodology that has been little explored (Hodgson et al., 2016; Hodgson et al., 2018; Lyons et al., 2019). The transformation of the RGB images acquired by the UAV into panchromatic images, through the use of GIS tools, makes it possible to isolate the object of study from the rest of the visual information, facilitating its subsequent quantification, both automatic and manual (Lyons et al., 2019), however, it is emphasized that the data referring to the eggs counted resulted from an underestimation of the real total, which depends on multiple factors. For this, it is ideal to obtain images with good lighting, as well as several photographic sweeps, since the individuals can stand up and leave the nest eggs in sight. Therefore, the proposed methodology in this study is presented as highly reliable, allowing the results of monitoring by direct observation in the field to be consolidated, as well as, the possibility to keep a file of the studied population dynamics over time (Jones et al., 2010; Lyons et al., 2019).

Regarding the effects caused by the UAV in the study population, in the experiments carried out on common flamingos (Phoenicopterus roseus) and other water birds no significant differences were observed in the response of individuals to UAV attending to their feeding and rest behavior, nor an effect after successive flights (Vas et al., 2015). However, in this work, it was necessary to modify the approach distance to the colony during 2019 surveys, where the minimum approach distance was higher $(30 \mathrm{~m})$. This factor was conditioned by the increase in the numbers of juvenile individuals who presented increased stress with the noise generated by the UAV, which was recorded in adult individuals with continuous flapping. This could be explained by the variations in individual behavior during the reproductive and non-reproductive period (Barisón et al., 2014; Derlindati et al., 2014) concerning stress sensitivity caused by the UAV.

Extraction activities have been conducted in Salinas lake from the 40's to the present (salt and borates), activities were considered as the main disturbances affecting the flamingo population (Ugarte-Nuñez \& MosaurietaEchegaray, 2000), as well as the installation of flooded plots, as they negatively affect the establishment of flamingos and other bird species. However, the results of this study show that these flooded areas present the right conditions to allow the establishment of nesting colonies, as they provide some protection against 
natural predators, and impede the extraction of eggs, which was also documented as a major threat in the area (Ugarte-Núñez \& MosaurietaEchegaray, 2000). Therefore, it seems that the flamingos living in this area have become habituated to the presence of people, vehicles and machinery. This would also be favored by the hydraulic dynamics of the Salinas lake, since in the monitoring of the water coverage of this lake for 2019, it arrives at its maximum capacity and coverage during February and March, then beginning a reduction where in September it is $47 \%$ of the total coverage, during these months the nesting colonies of Chilean flamingos are benefited by the creation of an exclusion zone by the areas still flooded until the end of the reproductive event.

Moreover, the practices to mitigate the impact of this mining activity, which include leveling the working areas and participatory management of this high Andean lake, between private companies, peasant communities, NGOs and the Peruvian State, are presented as successful, by maintaining this ecosystem in suitable conditions. The final results allow us to suggest some perspectives on the continuity of monitoring by SERNANP, in addition, to refine the methodology for estimating individuals and incorporate new tools in the UAV. Also, to tracking individuals born in Salinas by banding for monitoring for the conservation of the species as it is done in Chile and Bolivia.

Finally, the record of active nesting colonies of Chilean flamingos represents a relevant milestone in the conservation of this RAMSAR wetland (Ramsar, 2017) and the population of the species, which urges the main actors involved to continue developing and implementing complementary actions for its conservation, within which the inclusion of management plans is recommended, considering the identified nesting areas and their consequent monitoring.

Ethical statement: authors declare that they all agree with this publication and made significant contributions; that there is no conflict of interest of any kind; and that we followed all pertinent ethical and legal procedures and requirements. All financial sources are fully and clearly stated in the acknowledgements section. A signed document has been filed in the journal archives.

\section{ACKNOWLEDGMENTS}

We would like to thank the RNSyAB management for involving us in this collaborative research, and also Mr. Leopoldo Choque, official ranger of the RNSyAB for his collaboration in fieldwork. We would also thank INKABOR SAC Company for their support to perform this study within its work and exploitation area, as well as its good efforts in remediation and restoration actions in Salinas Lake.

\section{RESUMEN}

\section{Vehículos aéreos sin tripulación, y mapeo digital, para monitorear la reproducción del flamenco, Phoenicopterus chilensis (Aves: Phoenicopteridae)}

Introducción: Los flamencos altoandinos también conocidos como parihuanas, son especies con presencia recurrente en las zonas altoandinas, principalmente en humedales salinos donde suelen arribar para descanso, alimentación y en algunos casos reproducción. Las especies que se registran aquí corresponden a Phoenicoparrus jamesi, Phoenicoparrus andinus y Phoenicopterus chilenesis, siendo esta última la más abundante y común. Durante los censos desarrollados en 2018 y 2019, en la laguna de Salinas, ubicada en la Reserva Nacional de Salinas y Aguada Blanca en el sur del Perú, se registraron comportamientos atípicos de estas aves en un sector del humedal, se observaron cortejos reproductivos y el asentamiento de colonias de flamencos chilenos. Objetivo: Confirmar y evaluar eventos reproductivos de Phoenicopterus chilenesis mediante la incorporación de un vehículo aéreo no tripulado (UAV) y herramientas de procesamiento de imágenes mediante sistemas de información geográfica. Metodología: Se realizaron censos aéreos durante 2018 y 2019 a colonias reproductivas del $P$. chilensis, utilizando un UAV Phantom 4 a diferentes alturas de vuelo para evitar la perturbación de las colonias de flamencos. Se realizaron registros de fotografías aéreas y post procesamiento SIG con la creación de imágenes pancromáticas para la identificación y conteo de individuos y huevos automatizada, así como la verificación manual. Resultados: En 2018 se identificaron nidos y la presencia de seis huevos, entre marzo y junio donde el evento fue interrumpido, no se observaron pollos o juveniles durante este periodo. En 2019 la nidificación 
tuvo éxito, se contabilizó un mayor número de huevos (4066) con la formación de tres colonias reproductivas de 4 185 individuos adultos, se verificó la presencia de pollos y juveniles que alcanzaron un máximo de 1491 individuos. Conclusiones: Se confirman dos eventos reproductivos continuos de $P$. chilensis en la laguna Salinas, durante el 2019 incorporando varios nuevos individuos a la población inicial. La metodología aplicada en el tratamiento de imágenes permitió diferenciar entre individuos adultos y huevos, pero no permitió diferenciar juveniles, aunque las imágenes directamente adquiridas por el UAV permiten diferenciar los tipos de individuos para realizar un conteo manual.

Palabras clave: parihuana; nidificación; crianza; teledetección; dron.

\section{REFERENCES}

Asociación Ecosistemas Andinos. (2010). Plan de manejo con fines de conservación de las especies de aves amenazadas del lago Chinchaycocha: Zambullidor de Junin (Podiceps taczanowskii), Gallinetita de Junín (Laterallus tuerosii) y Parihuana (Phoenicopterus chilensis), en el Ámbito de la Reserva Nacional de Junín. Asociación Ecosistemas Andinos.

Barisón, C., Cruz, N., Romano, M., \& Barberis, I.M. (2014). Patrones de comportamiento de dos especies de flamencos (Phoenicoparrus andinus y Phoenicopterus chilensis) y su relación con las condiciones meteorológicas de la laguna Melincué, Argentina, durante el invierno. Hornero, 29(2), 61-71.

BirdLife International. (2018). Phoenicopterus chilensis. The IUCN Red List of Threatened Species. https:// www.iucnredlist.org/es/species/22697365/132068236

Borrelle, S.B., \& Fletcher, A.T. (2017). Will drones reduce investigator disturbance to surface-nesting seabirds? Marine Ornithology, 45, 89-94.

Caziani, S.M., Rocha, O., Rodríguez, E., Romano, M., Derlindati, E.J., Tálamo, A., Ricalde, D., Quiroga, C., Contreras, J.P., Valqui, M., \& Sosa, H. (2007). Seasonal Distribution, Abundance, and Nesting of Puna, Andean, and Chilean Flamingos. Condor, 109(2), 276-287. https://doi.org/10.1093/condor/109.2.276

Chabot, D., Craik, S.R., \& Bird, D.M. (2015). Population census of a large common tern colony with a small unmanned aircraft. PLOS ONE, 10, e0122588. https:// doi.org/10.1371/journal.pone.0122588

Derlindati, E.J., Romano, M.C., Cruz, N.N., Barisón, C., Arengo, F., \& Barberis, I.M. (2014). Seasonal activity patterns and abundance of Andean flamingo (Phoenicoparrus andinus) at two contrasting wetlands in Argentina. Ornitología Neotropical, 25, 317-331.
Dulava, S., Bean, W.T., \& Richmond, O.M. (2015). Environmental reviews and case studies: applications of unmanned aircraft systems (UAS) for waterbird surveys. Environmental Practice, 17(3), 201-210. https://doi.org/10.1017/S1466046615000186

Grémillet, D., Puech, W., Garçon, V., Boulinier, T., \& Maho, Y. (2012). Robots in Ecology: Welcome to the machine. Open Journal of Ecology, 2(2), 49-57. https://doi.org/10.4236/oje.2012.22006

Henriksen, M.V.J., Hangstrup, S., Work, F., Krogsgaard, M.K., Groom, G.B., \& Fox, A.D. (2015). Flock distributions of Lesser Flamingos Phoeniconaias minor as potential responses to food abundance-predation risk trade-offs at Kamfers Dam, South Africa. Wildfowl, $65,3-18$.

Hodgson, J.C., Mott, R., Baylis, S.M., Pham, T.T., Wotherspoon, S., Kilpatrick, A.D., \& Koh, L.P. (2018). Drones count wildlife more accurately and precisely than humans. Methods in Ecology and Evolution, 9(5), 1160-1167. https://doi. org/10.1111/2041-210X.12974

Hodgson, J.C., Baylis, S.M., Mott, R., Herrod, A., \& Clarke, R.H. (2016). Precision wildlife monitoring using unmanned aerial vehicles. Scientific Reports, 6, 22574. https://doi.org/10.1038/srep22574

Hurlbert, S.H., \& Keith, J.O. (1979). Distribution and spatial patterning of flamingos in the Andean altiplano. Auk, 96(2), 328-342.

Jones, G.P., Pearlstine, L.G., \& Percival, H.F. (2010). An assessment of small unmanned aerial vehicles for wildlife research. Wildlife Society Bulletin, 34, 750-758. https://doi. org/10.2193/0091-7648(2006)34[750:AAOSUA]2.0 . $\mathrm{CO} ; 2$

Krienitz, L., Krienitz, D., Dadheech, P.K., Hübener, T., Kotut, K., Luo, W., Teubner, R., \& Versfeld, W.D. (2016). Food algae for Lesser Flamingos: a stocktaking. Hydrobiologia, 775(1), 2-50. https://doi. org/10.1007/s10750-016-2706-x

Luque-Fernández, C.R. (2021, May 10). Supplementary video: Monitoring reproduction events of Phoenicopterus chilensis, Arequipa, Peru [Video file]. YouTube. https://www.youtube.com/watch?v=152Pmp9PxFc

Lyons, M.B., Brandis, K.J., Murray, N.J., Wilshire, J.H., McCann, J.A., Kingsford, R.T., \& Callaghan, C.T. (2019). Monitoring large and complex wildlife aggregations with drones. Methods in Ecology and Evolution, 10(7), 1024-1035. https://doi. org/10.1111/2041-210X.13194

Martínez, D., \& González, G. (2017). Aves de Chile. Guía de campo y breve historia natural. Ediciones del naturalista. 
McClelland, G.T.W., Bond, A.L., Sardana, A., \& Glass, T. (2016). Rapid population estimate of a surfacenesting seabird on a remote island using a low-cost unmanned aerial vehicle. Marine Ornithology, 44, 215-220.

Mendoza, L.F., Cortés, E., Sierra, C., \& Carmona, R. (2013). Avistamientos de flamencos (Phoenicopterus ruber) en la Reserva de la Biosfera Marismas Nacionales, Nayarit. Revista Mexicana de Ornitologia, 14(2), 84-86. https://doi.org/10.28947/ hrmo.2013.14.2.197

Polla, W.M., Di Pasquale, V., Rasuk, M.C., Barberis, I., Romano, M., Manzo, R.A., Paggi, J.C., Farías, M.E., Contreras, M., \& Devercelli, M. (2018). Diet and feeding selectivity of the Andean Flamingo Phoenicoparrus andinus and Chilean Flamingo Phoenicopterus chilensis in lowland wintering areas. Wildfowl, 68 , 3-29.

Ramsar. (2017). The List of Wetlands of International Importance (The RAMSAR list). RAMSAR. https:// www.ramsar.org/document/the-list-of-wetlands-ofinternational-importance-the-ramsar-list

Rodríguez, E. (2005). Flamencos altoandinos Phoenicopterus andinus (Philippi 1854), Phoenicopterus jamesi (Sclater 1886) y Phoenicopterus chilensis (Molina 1782), en el Norte de Chile: Estado actual y plan de conservación. Corporación Nacional Forestal (CONAF).
Sabella, G., Viglianisi, F.M., Rotondi, S., \& Cilea, F. (2017). Benefits in avifaunistic monitoring through the use of an unmanned aerial vehicle (UAV) in the Nature Reserve of Saline di Priolo (Sicily, Italy). Bulletin of the Entomological Society of Malta, 9, 121.

Schulenberg, T.S., Stotz, D.F., Lane, D.F., O’Neill, J.P., Parker III, T.A., \& Egg, A.B. (2010). Birds of Peru, revised and updated. Princeton University Press.

Ugarte-Núñez, J., \& Mosaurieta-Echegaray, L. (2000). Assessment of Threats to Flamingos at the Salinas and Aguada Blanca National Nature Reserve (Arequipa, Perú). Waterbirds: The International Journal of Waterbird Biology, 23,134-140. https://doi. org/10.2307/1522158

Vas, E., Lescroël, A., Duriez, O., Boguszewski, G., \& Grémillet, D. (2015). Approaching birds with drones: first experiments and ethical guidelines. Biology Letters, 11(2), 20140754. https://doi.org/10.1098/ rsbl.2014.0754

Vizcarra, J.K. (2014). Descripción de un evento reproductivo y desarrollo de polluelos de Phoenicopterus chilensis en los Humedales de Ite, costa sur del Perú. Boletín de la Unión de Ornitólogos del Perú (UNOP), 9(2), 28-39.

Winkler, D.W., Billerman, S.M., \& Lovette, I.J. (2020). Flamingos (Phoenicopteridae), versión 1.0. Birds of the World. Cornell Lab of Ornithology. https://doi. org/10.2173/bow.phoeni1.01 